\title{
State Control of Authorities, Responsibilities and Implementing Decisions of Water Resources Management
}

\author{
Prihatin Kusdini \\ \{dini_taufik@yahoo.com\} \\ Universitas 17 Agustus 1945 Jakarta, Jakarta, Indonesia
}

\begin{abstract}
This research aims to observe the quality control of the authorities towards the responsibility and implementation of all water resources management decisions. Water is a vital need for humans. Humans cannot live without water. This research used normative juridical method, empirical analytic method and qualitative research method. This research shows that a change in law is needed that is able to accommodate the water resources management as a quality control tool from the authorities towards the responsibility and implementation of water resources management decisions that are oriented towards development progress.
\end{abstract}

Keyword: Quality Control from Authorities, Responsibilities, Water Resources Management

\section{Introduction}

Science is a product of thinking that illuminates humans in finding their true selves and living a perfect life. Problems that occurencouragehumans to ask questions, think and look for ans wers to existing phenomena, which in the end humans will seek the truth. Science cannot be separated from the foundation of Ontology, Epistemology and Axiology. Ontology is the science that examines and explores everything that exists, part of the most general philosophy or metaphysics, discussing about everything, covering all forms of reality. Epistemology discusses the theory, how to get knowledge correctly through the right process, what is the truth itself and what are the criteria. Axiology studies science starting from the formulation of problems, frameworks, hypotheses and conclusions.[1].

Indonesia is a developing country that is rich in natural resources, where these natural resources have a very important role in life, es pecially water resources. In accordance with the fact that water is a source of life for all living things and humans have a responsibility in managing thesenatural resources. Wateris the necessity for daily life for humans so it takes responsibility to preserve nature so that the ecosystemis not damages due to global warming and human activity. Then the development strategy must be controlled so as not to damage the environment for the future of the offspring.[2].

The government issued Law No. 11 of 1974 about irrigation. State control water resources its own problems because it does nothave adequate resources for such management. Finally, in the 1990s efforts to attract private interest in the irrigation sector were intensified. These efforts are inseparable from the policies of the New Order government which is controlled by the strength of foreign capital. New order policies bring the State to dependence on foreign capital assistance which is always increasing. During the reform period, Law No. 7 of 2004 indicated many articles that perpetuate the efforts to privatize and commercialize water resources so that they get a lot of challenges from various groups. [3]. 


\section{Purpose}

a. To find out the quality control mechanism of the implementation, the decision on the distribution of authority, the responsibility in carrying out the management of water resources and the responsibility in maintaining water absorption.

b. To find out the engagement between the government and the manager of water resources in Indonesia.

\section{Method}

a. Normative Juridical Method

The method of normative juridical approach is the method of approach by examining the rule of law or based on written law, concerning the principles, comparis ons, and history of law. Juridical approach to legal res earch is research by referring to the study of literature or secondary data used.[4].

b. Analytical Empirical Method

Analytical empirical research methods havebecome an important method of finding good law and accepted legal principles and as a principle of justice in law. Research refers to data derived fromevents / facts in life supported by indepth analy sis based on event data.[5].

c. Qualitative Method

Qualitative research methods are descriptive research supported by analysis. The results of the analysis do not depend on the data in terms of quantity (quantitative) but the data in the analysis from various angles in depth and holistically (holistic), aims to describe a phenomenon with complete and indepth data. [6].

\section{Results and Dis cussion}

Why water is so important to pay attention to it, because water is a vital community need, very important source of livelihood because without water there is no life. With the importance of water for life, the water resources management is also very important to consider. Water as a public need has a social function, where the use of water takes precedence for the public interest not only for the benefit of individuals. In the next development, water becomes an economic functioning item. The emergence of water as an economic itemis inseparable from the influence of the neoliberal economy with the United States and Britain as its pioneers.[7].

Law No. 7 of 2004 About Water Resources was declared invalid after the reenactment of Law No. 11 of 1974 concerning Irrigation. The entire legis lation is derived from Law No. 7 of 2004 does not apply and cannot be used as a legal basis for the formulation of policies and regulations for water resources management system. Law No. 11 of 1974 About Irrigation until now there is still no advanced software such as the rules of its 
implementation, while the exis ting problems are increasingly complex, this results in mutual disturbances.[8].

With the amendment to the 1945 Constitution resulting from the amendment and the emergence of a new law on regional autonomy in which each region feels more entitled especially in matters of filling the coffers through taxes and so on. In the current legal is sues in Indonesia, there is a great overlap between one regulation and another, because the structure of thought of the exis ting laws does not pay attention to the master rules, namely the 1945 Constitution. After in the 4th amendment, while we are referring to the 1945 Constitution. Even this situation becomes more difficult because of overlapping rules, as is the case at this time of dispute.[9].

Law No. 7 of 2004 concerning Water Resources was declared invalid after the reenactment of Law No. 11 of 1974 concerning Irrigation. The entire legislation is derived from Law No. 7 of 2004 does not apply and cannot be used as a legal basis for the formulation of policies and regulations on water resources management. Based on Law No. 11 of 1974 concerning Irrigation Considering a) that water and its sources, including the natural wealth contained therein, are a gift of God Almighty that has vers atile benefits and are needed by humans of all time, both in the economic, social and cultural fields; $b$ ) that the earth and water and the natural res ources contained therein are controlled by the State and used for the maximum pros perity of the people fairly and equally; c) that its utilization must be devoted to the interests and welfare of the people which at the same time creates growth, social jus tice and the ability to stand on their own strength towards a just and prosperous society based on Pancasila; d) that Algemeen Waterreglement in 1936 did not apply to all of Indonesia and the other laws and regulations relating to irrigation were felt to be no longer in accordance with developments and the current situation; e) that for the implementation of the aforementioned purposes, it is necessary to have a law concerning irrigation that is national in nature and adapted to the development of the situation in Indonesia, both in terms of economic, social and technological as pects, to be used as a basis for the drafting of further legislation. As in article 2, water and its sources, including the natural resources contained therein, as referred to in article 1 numbers 3,4 and 5 "Water is all water contained in and or originating from water sources, both which exists above or below the surface of the land, is not included in this sense water contained in the sea. "This law has a social function and is used for the greatest prosperity of the people. Roscu Pound points to another goal of law, namely the welfare of all and every citizen, this is an ideal welvaartstaat, or welfare state, focused on the Pancasila philosophy which requires the achievement of social justice, as stated in the opening of the 1945 Constitution.[10].

Smith argues that the main and necessary condition for the continuation of community life is justice which is a requirement that must be created for the formation of s ociety. Justice is the main pillar supporting all buildings of people's lives. Logically, if this milestone is destroyed, then the community building will surely collapse and be destroyed. So that humans cannot survive if in their lives they hurt and hurt each other, so the conclusion is that society will not exist without jus tice. Besides justice, the other supporting pillars are moral and distributivejus tice. Communities can survive in miserable conditions but people will not be able to live when injustice is rampant, one another hurting each other. Likewise, Leonard Billet also emphasized jus tice as the guardian of community life preservation. According to Smith, justice becomes a major element in economic activity. Justice is a prerequisite for the functioning of ethical business relations in the free market system. In this case, business must not be detrimental to one another. Not only in terms of moral restrictions, but als o must be included in the legal rules of law to furtherbecome rules of the game that must be obeyed 
for business people.[11].

Considering the importance of water as the source of life for all living things, since the founding of this country, the regulation of water has been included in the constitution of the Republic of Indonesia in Article 33 paragraph (3) of the 1945 Constitution of the Republic of Indonesia, "The earth and water and the natural resources contained therein are controlled by the state and used for the greatest prosperity of the people".[12].

Recognition of the state as a rule of law is very important, because political power and the state are not unlimited. The need for limits on the authority and power of the state so that there is no arbitrary action by the ruling party. Restrictions on political and state power must be clear so that no one is violated. The concept in countries with the enactment of the Common Law is also called. "government based on law" as well as the famous term Government Under the Law "governance under the law". The rule of law "Rechtstaat" has a parallel meaning to the rule of law, which is intended as an effort to limit the power of state authorities so as not to abuse power to oppress the people. In the rule of law no one is above the law, including its own ruler. The rule of law is the system of the State based on the law in the regulation of the life of the state that is applied fairly in a form of a constitution in which all colors of the State are obliged to comply with the law, so that the government does not arbitrarily violate the rights of its people.[13].

\section{Conclusion}

1. Based on article 33 of the 1945 Constitution water control is managed by the state because it involves the livelihood of humans, supervision, control by the state of water is absolutely the main priority of water exploitation by BUMN, BUMD and if there is still water availability it is still possible to be managed privately with certain conditions and tight.

2. Article 33 of the 1945 Constitution paragraph 3 is the mandate of the people granted to the government, it's to ensure the prosperity of the people.

3. Article 33 of the 1945 Constitution paragraph 5 for further regulation by law, so water resources management regulation in a law has a legal basic.

4. The right of water is a separate human right article 28 I paragraph 4 of the 1945 Constitution, protection, promotion, enforcement and fulfillment of human rights are the responsibility of the state, and article $28 \mathrm{H}$ paragraph 1 determines "Every pers on has the right to prosperity physically and mentally, residing and receiving good and healthy environment and the right to obtain health services ".

\section{References}

[1] Bahrum, The Ontology, Epistemology and Axiology, Sules ana, Volume 8 No. 2, 2013

[2] Al Qur'an, $S: 2.30$

[3] Adhi Prasetyo, The Analysis of Breaches of Water Resources Law, Adhiprasetyo.blogs pot.co.id, 21 April 2006

[4] Yulia Tan, Juridical Normative Research Metodology. www.docplayer.info, 2018

[5] Metodologi Penelitian, metopenkomp.blogspot.com, 2017

[6] Penelitian Kualitatif, www.id.wikipedia.org, April 2019

[7] LPPSLH, MelihatPerlakuan Negara terhadap Sumber Daya Air di Indonesia, LPPSLH, 
3 April 2014, hlm. 1

[8] Amrizal Nasution, "DampakPembatalan UU Sumber Daya Air", Harian Analisa, 3 Mei 2015:1

[9] Maria Farida Indrati S, Ilmu Perundang-undangan, Cet. Ke 4, Yogyakarta: Kanisius, 2008, hlm. 85.

[10] Sunaryati Hartono, Hukum Ekonomi Pembangunan Indonesia, Bandung: Percetakan Binacipta, 1988, hlm. 16

[11] Sonny Keraf, Pasar Bebas Keadilan dan Peran Pemerintah, Yogyakarta:Kanisius, 1996 [12] UUD 1945, Amandemen Ke 4, 10 Agustus 2002

[13] MunirFuady, Teori Negara Hukum Modern (Rechtstaat). Bandung: Refika Aditama, hlm. 1-3 